\title{
PARADOKS DAN IMPLIKASINYA DALAM HUMOR BERTEMA KORUPSI
}

\author{
(Paradox and Its Implications in Corruption-Themed Humours)
}

\author{
Ai Kurniati \\ Balai Bahasa Kalimantan Tengah \\ Jalan Tingang Km 3,5, Palangka Raya, Kalimantan Tengah, Indonesia \\ Posel: ai.kurniati@gmail.com
}

\begin{abstract}
Abstrak: Humor bertema korupsi muncul bersamaan dengan maraknya kasus korupsi yang mencuat di negeri ini. Keistimewaan paradoks dalam humor yang bertemakan korupsi ialah opini atau argumen yang berlawanan dengan pendapat umum dapat dianggap aneh atau luar biasa. Tulisan ini membahas wujud paradoks beserta implikasinya dalam wacana humor yang bertema korupsi. Tujuannya adalah mendeskripsikan wujud paradoks dan implikasinya dalam wacana humor yang bertema korupsi. Penelitian ini merupakan penelitian deskriptif dengan uraian yang bersifat kualitatif. Berdasarkan temuan terdapat enam wacana humor politik yang bertemakan korupsi yang memanfaatkan gaya bahasa paradoks.
\end{abstract}

Kata Kunci: paradoks, implikasi, humor korupsi

Abstract: The corruption-themed humours come along with the increasing number of corruption cases in this country. The uniqueness of paradox in the corruption-themed humours is a contrary opinion or argument to popular opinion could be considered as strange or extraordinary. This paper discusses the form of paradox along with its implications in the corruption-themed humour discourse. This paper aims to describe the form of paradox and its implications in corruption-themed humour discourse. This is a descriptive paper and uses qualitative explanation to elaborate the data. Based on the findings, there are six political humour discourses with the corruption-themed humour which contains paradox language style.

Keywords: paradox, implication, corruption humour

\section{PENDAHULUAN}

Humor hidup di semua lapisan masyarakat baik di desa maupun kota. Humor dilakukan oleh seseorang atau kelompok orang untuk melampiaskan perasaan tertekan dan bertujuan untuk mengurangi berbagai ketegangan yang ada di sekeliling manusia. Humor sebagai suatu keadaan atau gejala yang dapat menimbulkan efek tertawa merupakan suatu unsur yang sering dijumpai di dalam kehidupan sehari-hari. Humor terdapat di mana-mana, tidak mengenal kelas sosial, latar pendidikan, dan tinggi rendahnya inteligensi manusia.

Korupsi sudah menjadi kata yang sudah tidak asing lagi didengar, dilihat, dibaca, bahkan dalam bentuk tertentu dianggap lazim ketika dilakukan. Menurut KBBI korupsi adalah penyelewengan atau penyalahgunaan uang negara, perusahaan, dan sebagainya untuk keuntungan pribadi atau orang lain. Praktik korupsi, seperti penyuapan, terjadi di semua level birokrasi pemerintahan mulai dari level terendah hingga level tertinggi. 
Praktik korupsi di Indonesia sudah sangat parah sehingga mendudukkan Indonesia sebagai salah satu negara terkorup di dunia. Semua hal dikorupsi di negeri ini. Negeri yang kaya raya dan indah permai ini habis diperas para tikus dan bandit. Sampai muncullah humorhumor yang menertawakan kelakuan para koruptor di negeri sendiri. Rakyat Indonesia pun seolah-olah dipaksa menertawakan sesuatu yang paradoksal. Amati wacana humor bertema korupsi yang berupa teka-teki di bawah ini.

"Apa bedanya korupsi zaman Orde Lama, Orde Baru, dan zaman sekarang?“" Jawabannya adalah zaman Orde Lama korupsi sembunyi-sembunyi, dilakukan di bawah meja. Zaman Orde Baru, sudah mulai berani, korupsi dilakukan di atas meja. Nah, zaman sekarang, bahkan meja-mejanya pun ikut dikorupsi.

Kajian mengenai humor sudah banyak dilakukan antara lain oleh Surachmi (2011) yang mengkaji humor dari segi sosiolinguistik; Riniwati (2011), Santoso, dkk. (2012), Kurniati (2014), dan Rahayu (2014) yang mengkaji humor dari segi pragmatik; Lestari (2013) mengkaji humor dari sisi tema dan gaya bahasa secara umum; dan Rohim (2014) yang mengkaji humor dari perspektif sastra (hermeneutika).

Berdasarkan beberapa kajian terdahulu masalah humor sudah banyak dibahas. Berbeda dengan beberapa kajian di atas, tulisan ini mengungkap humor bertemakan korupsi dari gaya bahasanya, khususnya paradoks beserta implikasinya. Berdasarkan hal tersebut penulis merasa tertantang untuk membahas masalah korupsi, tepatnya humor yang bertemakan korupsi. Humor korupsi yang dimaksud adalah humor yang memiliki topik mengenai korupsi. Humor bertema korupsi muncul bersamaan dengan maraknya kasuskasus korupsi yang mencuat di negeri ini.
Permasalahan yang dikaji dalam tulisan ini ialah bagaimana wujud paradoks beserta implikasinya dalam wacana humor yang bertema korupsi. Data yang dijadikan objek dalam tulisan ini diambil dari kumpulan humor bertemakan korupsi dari situs www.merdeka.com dan www.ketawa. com. Data yang dijadikan objek dalam tulisan ini diambil dari wacana humor dengan jenis humor politik. Berdasarkan data tersebut terdapat enam wacana humor politik yang bertemakan korupsi yang memanfaatkan gaya bahasa paradoks.

Menurut Kridalaksana (2001, hlm. 63) gaya bahasa (style) mempunyai tiga pengertian, yaitu pemanfaatan atas kekayaan bahasa oleh seseorang dalam bertutur atau menulis; pemakaian ragam tertentu untuk memperoleh efek-efek tertentu; keseluruhan ciri-ciri bahasa sekelompok penulis sastra. Zaimar dan Harahap (2015, hlm. 184) mengemukakan bahwa pemakaian gaya bahasa yang tepat dapat menarik perhatian penerima. Sebaliknya, jika penggunaannya tidak tepat, gaya bahasa tersebut akan sia-sia, bahkan mengganggu penerima dan pembaca.

Gorys Keraf (2008, hlm. 124145) membagi gaya bahasa berdasarkan struktur kalimat yang meliputi (1) klimaks, (2) anti-klimaks, (3) paralelisme, (4) antitesis, dan (5) repetisi (epizeuksis, tautotes, anafora, epistrofa, simploke, mesodiplosis, epanolepsis, dan anadiplosis); berdasarkan langsung tidaknya makna meliputi (1) gaya bahasa retoris yang terdiri atas aliterasi, asonansi, anastrofa, apofasis (preterisiso), apostrof, asinden-ton, polisindenton, kiasmus, elipsis, eufemisme, litotes, histeron prosteron, pleonasme dan tautologi, perifrasis, prolepsis, erotesis, silepsis dan zeugma, koreksio, hiperbola, paradoks dan oksimoron; (2) gaya bahasa kiasan meliputi persamaan atau simile, 
metafora, alegori, parabel, fabel, personifikasi, alusi, eponim, epitet, sinekdok, metonimia, antonomasia, hipalase, ironi, sinisme dan sarkasme, satire, innuendo, dan antifrasis.

Dari beberapa pendapat di atas dapat disimpulkan bahwa gaya bahasa dapat dibedakan menjadi lima kelompok, yaitu (1) gaya bahasa perbandingan yang meliputi hiperbola, metonimia, personifikasi, metafora, sinekdok, alusi, simile, asosiasi, eufemisme, pars pro toto, epitet, eponim, dan hipalase; (2) gaya bahasa perulangan yang meliputi aliterasi, anafora, anadiplosis, mesodiplosis, epanolipsis, dan epizeuksis; (3) gaya bahasa sindiran yang meliputi ironi, sinisme, innuendo, sarkasme, satire, dan antifrasis; (4) gaya bahasa pertentangan yang meliputi paradoks, antitesis, litotes, oksimoron, dan histeron prosteron; (5) gaya bahasa penegasan yang meliputi repetisi dan paralelisme.

Gorys Keraf (2008, hlm. 144) menyatakan bahwa paradoks adalah semacam gaya bahasa yang mengandung pertentangan yang nyata dengan faktafakta yang ada. Zaimar dan Harahap (2015, hlm. 197) menyatakan bahwa paradoks adalah opini atau argumen yang berlawanan dengan pendapat umum, dapat dianggap aneh atau luar biasa. Seringkali di balik gagasan yang mengherankan paradoks menyembunyikan kebenaran yang dapat dipertahankan. Dua penanda dalam paradoks memiliki makna oposisi. Kedua penanda muncul, tetapi tidak bersifat implisit. Oposisi ada hanya dalam makna kata, sedangkan di dalam kehidupan seringkali paradoks tidak merupakan oposisi, tetapi menguatkan makna. Berdasarkan beberapa pendapat di atas dapat disimpulkan bahwa gaya bahasa paradoks adalah gaya bahasa yang katakatanya mengandung pertentangan dengan fakta yang ada. Contohnya ungkapan Musuh sering merupakan kawan akrab.

\section{METODE PENELITIAN}

Metode dan teknik penelitian ini terbagi atas tiga tahap sesuai dengan yang disarankan Sudaryanto (1993, hlm. 5-8), yaitu metode dan teknik penyediaan data, metode dan teknik penganalisisan data, dan metode dan teknik penyajian data. Penyediaan data dilakukan dengan pengamatan terhadap humor yang bertemakan korupsi yang telah ditetapkan dengan menggunakan teknik pengartuan data dan mendeskripsikan segala hal yang berhubungan dengan gaya bahasa paradoks.

Tahap berikutnya menyeleksi data yang sudah terkoleksi. Kegiatan ini bertujuan untuk menajamkan, menggolongkan, mengarahkan data yang akan dipakai, membuang data yang tidak perlu, serta mengorganisasi data hingga simpulan-simpulan finalnya dapat ditarik dan diverifikasi. Dalam proses ini, data dipilih sesuai dengan rumusan masalah dan tujuan penelitian.

Analisis dimulai dengan pemilahan data yang sudah terkumpul. Kegiatan ini berlangsung hingga didapatkan data-data yang sesuai kemudian dilanjutkan pada tahap berikutnya, yakni penganalisisan.

Kegiatan selanjutnya yakni penyajian hasil analisis. Tahap ini adalah kegiatan-kegiatan analisis dalam bentuk mengorganisasi dan menyusun data menjadi informasi bermakna ke arah simpulan penelitian. Penyajian hasil analisis dapat dilakukan dengan dua cara, yaitu formal dan informal (Sudaryanto, 1993, hlm. 145). Metode penyajian formal berupa perumusan kaidah-kaidah tabel-tabel dan diagram, sedangkan metode penyajian informal berupa eksplanasi biasa, yaitu perumusan dengan menggunakan kata-kata biasa. Dalam penelitian ini penyajian hasil analisis hanya menggunakan metode penyajian informal berupa penjelasan biasa, yaitu perumusan dengan menggunakan kata-kata biasa. 


\section{PEMBAHASAN}

\section{Gaya Bahasa Paradoks dalam Humor Korupsi}

Data yang dijadikan objek dalam tulisan ini diambil dari kumpulan humor disitus www.merdeka.com dan www. ketawa.com. Data yang dijadikan objek dalam tulisan ini diambil dari wacana humor dengan jenis humor politik. Berdasarkan data tersebut ditemukan wacana humor politik yang bertemakan korupsi yang memanfaatkan gaya bahasa paradoks.

Pengambilan sampel data dilakukan dengan purposive sampling, yaitu dengan mengambil data yang berkaitan dengan kajian paradoks yang akan dilakukan. Sesuai dengan maksud penelitian terdapat enam data wacana humor korupsi yang dianalisis. Analisis data dapat dilihat sebagai berikut.

\section{Data 1}

\section{Korupsi Jumlah Lantai Rumah Sakit}

Tiga orang pejabat rumah sakit dari Benua Amerika, Benua Eropa, dan Indonesia bertemu. Mereka saling membanggakan kelihaian mereka korupsi. Orang Amerika: "Lihat bangunan RS itu? Ada 9 lantai. "Orang Eropa dan Indonesia menghitung: "Kok cuma 8 lantai? "Si Koruptor Amerika tersenyum. Orang Eropa dan Indonesia mengangguk-angguk paham. "Ooh,

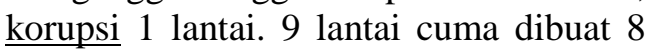
lantai."

Giliran Koruptor Eropa unjuk gigi.Dia menunjuk bangunan RS di kejauhan. "Lihat itu, RS 11 lantai. "Orang Amerika dan Indonesia menghitung: "Kok cuma 7 lantai? "Si Eropa tersenyum. Mereka segera paham. "Ooh, korupsi 4 lantai.

"Kini tiba bagian orang Indonesia. Dia menunjuk ke sebuah bukit. "Lihat itu, gedung RS 21 lantai yang sangat megah, bukan?" Orang Eropa dan Amerika kebingungan. "Mana kok sama sekali tidak ada gedung RS di bukit itu? "Koruptor dari Indonesia
tersenyum."Itulah hebatnya koruptor di Indonesia," katanya.

(http://www.merdeka.com)

Data (1) merupakan wacana humor yang bertemakan korupsi. Diawali dengan bertemunya tiga orang pejabat rumah sakit dari Benua Amerika, Eropa, dan Indonesia. Mereka saling menyombongkan diri akan kemahirannya dalam berkorupsi. Satu per satu dari mereka memamerkan hasil korupsinya seperti yang diucapkan orang Amerika, "Lihat bangunan RS itu? Ada 9 lantai." Padahal, jelas terlihat oleh orang Eropa dan Indonesia hanya delapan lantai. Koruptor Amerika pun tersenyum bangga. Akhirnya dipahami juga oleh orang Eropa dan Indonesia bahwa orang Amerika hanya korupsi satu lantai.

Tiba giliran koruptor Eropa unjuk gigi dengan menunjuk bangunan RS di kejauhan kemudian berujar, "Lihat itu, RS 11 lantai." Orang Amerika dan Indonesia menghitung cuma tujuh lantai. Kemudian orang Eropa pun tersenyum bangga. Ternyata orang Eropa hanya korupsi empat lantai.

Tiba giliran orang Indonesia yang menunjuk ke sebuah bukit dan berkata, "Lihat itu, gedung RS 21 lantai yang sangat megah, bukan?" Jelas saja orang Eropa dan Amerika kebingungan karena sama sekali tidak ada gedung RS di bukit itu. Koruptor dari Indonesia juga tersenyum, "Itulah hebatnya koruptor di Indonesia," katanya.

Bukti adanya paradoks tampak jelas pada pernyataan koruptor paling akhir, yaitu dari Indonesia. Pernyataannya paradoksal, yaitu dengan menunjuk sebuah bukit yang sama sekali tidak terdapat gedung rumah sakit, tetapi koruptor tersebut mengungkapkan bahwa di situ terdapat gedung rumah sakit 21 lantai yang sangat megah. Dikatakan paradoks karena pernyataannya mengandung pertentangan yang nyata dengan fakta yang ada. 
Terdapat implikasi makna yang terkandung dalam wacana humor bertemakan korupsi di atas, antara lain banyaknya manusia yang tidak jujur sehingga mengungkapkan sesuatu yang tidak sesuai dengan kenyataan (fakta) yang ada; banyaknya manusia yang merasa bangga sudah berhasil melakukan kegiatan kriminal (korupsi); dan negara Indonesialah yang juara dalam hal korupsi.

Dengan menggunakan gaya bahasa paradoks itulah dibeberkan fakta yang sebenarnya terjadi. Manusia seharusnya merasa malu jika melakukan sebuah kejahatan (apa pun bentuknya), bukannya merasa bangga. Sebaliknya, manusia seharusnya merasa bangga jika telah berprestasi dalam hal positif (bukan hal merugikan negara). Wacana humor data (1) sungguh sangat menggelitik karena diungkapkan dengan gaya bahasa paradoks yang jenaka.

\section{Data 2}

\section{Lift di Monas Rusak}

Alkisah, suatu hari lift di Monas rusak. Sesuai aturan diadakan tender untuk memperbaiki lift itu. Pesertanya kontraktor dari Prancis, Korea, dan Indonesia. Setelah melihat kerusakan, masing-masing melakukan presentasi secara terpisah. Kontraktor Prancis: Hasil hitungan kami total biaya Rp10 miliar. Kontraktor Korea: Ah, kami berani cuma Rp5 miliar saja. Kontraktor Indonesia: Kalau menurut kami, ini setidaknya butuh Rp15 miliar. Pemerintah Indonesia: Lho kok, dari Indonesia malah lebih mahal? Si kontraktor Indonesia pun berbisik pelan-pelan. "Gini Bung, Rp5 miliar untuk saya, Rp 5 miliar lagi buat Bung. Nah, $5 \mathrm{M}$ lagi biarkan si orang Korea yang kerja, oke?

(http://www.merdeka.com)

Konteks percakapan pada contoh data (2) terjadi antara kontraktor Prancis, Korea, dan Indonesia yang sedang lelang perbaikan lift Monas yang rusak. Kontraktor Prancis menyatakan bahwa hasil hitungan total biaya Rp10 miliar, kontraktor Korea menyatakan hanya berani Rp5 miliar, sedangkan kontraktor Indonesia menyatakan bahwa setidaknya butuh Rp15 miliar. Jelas saja itu membuat pemerintah Indonesia terkejut. Kemudian mulailah aksi kontraktor Indonesia yang membuat kesepakatan, seperti pada pernyataan: "Gini Bung, Rp 5 miliar untuk saya, Rp 5 miliar lagi buat Bung. Nah, 5 M lagi biarkan si orang Korea yang kerja, oke?".

Praktik korupsi pada wacana humor data (2) di atas terlihat dari pernyataan kontraktor Indonesia. Pernyataan tersebut jelas memanfaatkan gaya bahasa paradoks karena pernyataannya memuat pertentangan yang nyata dengan fakta yang sesungguhnya terjadi. Paradoks tersebut terlihat pada pernyataan kontraktor Indonesia yang memberikan harga yang fantastis, bukan seluruhnya dimanfaatkan untuk perbaikan, melainkan untuk kerja sama berbagi keuntungan dengan pihak lain (pemerintah).

Implikasi makna yang terkandung dalam wacana humor data (2) antara lain koruptor Indonesia pandai menaikkan harga lelang yang seharusnya lebih murah dari pada tenaga kerja dari negara lain, lihai bekerja sama dengan pihak lain (termasuk pemerintah) untuk berbagi keuntungan, dan sangat profesional terlihat dari perencanaan yang matang dan terstruktur. Alih-alih untuk membangun negara dan bangsa ini menjadi lebih baik dan maju, para pemegang kekuasaan ini malah menggerogoti negara dengan sangat serakah. Paradoks yang terdapat dalam wacana humor bertemakan korupsi di atas dimanfaatkan pencipta wacana tersebut agar wacana ciptaannya memiliki efek humor. 


\section{Data 3}

\section{Perampok dan Koruptor}

Dua orang perampok mencegat sebuah mobil mewah. Mereka menodongkan pistol pada empat orang pria berpakaian necis di dalamnya. "Serahkan uang kalian, "kata perampok itu. Seseorang yang berdasi menjawab dengan congkak. "Beraninya kalian merampok kami. Aku adalah anggota DPR, pria di sampingku adalah pejabat pajak. Dua orang di belakang adalah kepala keuangan di kementerian pemerintah. Kami baru rapat membahas anggaran, "katanya. Kedua perampok cuma tersenyum lalu kembali menodong para pejabat. "Kalau begitu, Tuan-Tuan, kembalikan uang kami yang kalian rampok," kata perampok itu. (http://www.merdeka.com)

Wacana humor pada data (3) terjadi percakapan antara tokoh perampok dan empat orang pria berpakaian necis. Perampok tersebut menodongkan sebuah pistol kepada mereka dan meminta mereka menyerahkan uang. Salah satu dari pejabat-pejabat itu menyela dengan gaya arogan, "Beraninya kalian merampok kami. Aku adalah anggota DPR, pria di sampingku adalah pejabat pajak. Dua orang di belakang adalah kepala keuangan di kementerian pemerintah. Kami baru rapat membahas anggaran." Kemudian tokoh perampok pun tersenyum sambil kembali menodong mereka dan berkata, "Kalau begitu, Tuan-Tuan, kembalikan uang kami yang kalian rampok."

Paradoks tampak pada pernyataan tokoh perampok di atas. Mengamati kalimat terakhir pada wacana tersebut, Kalau begitu, Tuan-Tuan, kembalikan uang kami yang kalian rampok" mengandung pertentangan dengan pernyataan pada awal kalimat, Serahkan uang kalian. Pertentangan tersebut merupakan ciri khas paradoks yang kerap dimunculkan untuk memaknai suatu fakta yang sesungguhnya.

Terdapat implikasi makna yang terkandung dalam wacana humor data
(3). Yang pertama, kearoganan yang sering ditunjukkan oleh para penguasa atau pejabat dalam berbagai kesempatan, bahkan pada situasi sulit sekalipun. Kedua, pejabat pemerintah atau penguasa dimaknai sebagai perampok uang rakyat. Ketiga, pejabat pemerintah atau penguasa yang berpakaian rapi dan necis ternyata lebih "rampok" daripada rampok yang sesungguhnya. Data (3) dengan paradoksnya telah membuat wacana tersebut memiliki daya humor yang memikat.

\section{Data 4}

\section{Proyek Jembatan Surga dan}

\section{Neraka}

Untuk kepentingan komunikasi, penghuni neraka dan surga akhirnya sepakat membangun jembatan untuk menghubungkan dua tempat yang bedanya sejauh langit ketujuh itu. Pembangunan jembatan dilakukan kedua pihak dan direncanakan bertemu di tengah-tengah. Enam bulan berjalan, penghuni surga baru menyelesaikan 25 persen. Sementara penghuni neraka hampir selesai. Malaikat pengawas pun melakukan sidak. Para penghuni surga mengakui kerja mereka lambat. "Kami di dunia beribadah, hanya berdoa. Belum pernah mengerjakan proyek semacam ini," kata mereka. Sementara di neraka, baru melihat daftar penghuni neraka, malaikat pengawas sudah paham kenapa pekerjaannya cepat. Di neraka ada ribuan mantan kontraktor proyek, pengembang, pejabat badan pertanahan, pejabat dinas pekerjaan umum, bahkan menteri pun ada. Pantas, sudah berpengalaman.

(http://www.merdeka.com)

Data (4) di atas merupakan wacana humor bertemakan korupsi yang memiliki konteks di surga dan neraka. Penghuni neraka dan surga sepakat membangun jembatan untuk menghubungkan dua tempat tersebut. Pembangunan tersebut dilakukan kedua pihak. Setelah enam bulan penghuni surga baru menyelesaikan sekitar 25 persen, 
sementara penghuni neraka cepat sekali menyelesaikan proyek itu. Malaikat pengawas kemudian melakukan inspeksi mendadak. Penghuni surga pun mengakui kerja mereka lambat dan berkata, "Kami di dunia beribadah, hanya berdoa. Belum pernah mengerjakan proyek semacam ini." Malaikat pengawas melihat daftar penghuni neraka dan akhirnya paham kenapa pekerjaan mereka sangat cepat. Ternyata di neraka ada ribuan mantan kontraktor proyek, pengembang, pejabat badan pertanahan, pejabat dinas pekerjaan umum, bahkan menteri.

Pemanfaatan gaya bahasa paradoks pada data (4) di atas dapat diamati dari pernyataan tokoh malaikat pada kalimat terakhir, Pantas, sudah berpengalaman. Malaikat tersebut sedang memeriksa hasil kerja pembangunan jembatan penghubung yang dibangun oleh para penghuni neraka. Awalnya heran pekerjaan mereka begitu cepat diselesaikan. Namun, hanya dengan melihat daftar penghuni neraka, yang notabene mantan kontraktor proyek, pengembang, pejabat badan pertanahan, pejabat dinas pekerjaan umum, bahkan menteri, malaikat langsung paham akan pengalaman mereka selama hidup di dunia. Data (4) di atas mengandung pernyataan paradoks karena isinya memuat pertentangan yang nyata dengan fakta yang ada.

Implikasi makna yang terdapat pada wacana humor data (4) antara lain para pejabat pemerintahan dan unsur yang terkait dapat dikatakan sebagai pelaku korupsi yang andal dan berpengalaman, para pejabat pemerintahan dan unsur yang terkait menjadikan korupsi sebagai gaya hidup mereka di mana pun berada, dan pekerjaan para pejabat pemerintahan dan unsur yang terkait malah merugikan bangsa dan negara. Strategi paradoks inilah yang membuat wacana bertemakan korupsi tersebut lucu.

\section{Data 5}

Kisah Pengadilan Tindak Pidana Korupsi

Pada puncak pengadilan korupsi, jaksa penuntut umum menyerang saksi, "Apakah benar," teriak dia, "bahwa Anda menerima lima ribu dolar untuk berkompromi dalam kasus ini?" Saksi menatap keluar jendela seolah-olah dia tidak mendengar pertanyaan.

"Bukankah benar bahwa Anda menerima lima ribu dolar untuk berkompromi dalam kasus ini?" ulang pengacara. Saksi masih tidak menanggapi. Akhirnya, hakim berkata, "Pak, tolong jawab pertanyaan jaksa." "Oh, maaf," saksi terkejut sambil berkata kepada hakim, "Saya pikir dia tadi berbicara dengan Anda."

(http://www.ketawa.com/2012/03/741

2)

Wacana humor data (5) merupakan percakapan antara tokoh jaksa penuntut umum, pengacara, hakim, dan saksi dalam sidang pengadilan korupsi. Jaksa penuntut umum mencecar saksi dengan pertanyaan, "Apakah benar, bahwa Anda menerima lima ribu dolar untuk berkompromi dalam kasus ini?" Saksi pun tidak menggubris pertanyaan dari jaksa penuntut umum. Kemudian pengacara mempertanyakan hal yang sama kepada saksi, "Bukankah benar bahwa Anda menerima lima ribu dolar untuk berkompromi dalam kasus ini?" Saksi persidangan tersebut masih tidak menanggapi pertanyaan dari pengacara. Akhirnya, giliran hakim yang bicara kepada saksi, "Pak, tolong jawab pertanyaan jaksa. Saksi pun terkejut dan berkata kepada hakim, "Oh, maaf, saya pikir dia tadi berbicara dengan Anda."

Mencermati kalimat terakhir data (5) di atas terdapat wujud paradoks yang digunakan pembuat wacana humor tersebut. Pada kalimat terakhir tokoh saksi malah mengungkapkan Saya pikir dia tadi berbicara dengan Anda kepada hakim. Kalimat tersebut dikatakan 
mengandung paradoks karena isinya sangat bertentangan dengan fakta yang ada (pernyataan sebelumnya). Pada pernyataan sebelumnya justru saksilah yang sesungguhnya dicecar pertanyaan.

Implikasi makna yang terkandung dalam wacana humor korupsi data (5), yaitu banyaknya aparat penegak hukum (pengadilan) yang tidak jujur, praktik korupsi yang marak dilakukan oleh aparat penegak hukum (pengadilan), dan banyaknya jual beli kasus (politik suap) antaraparat penegak hukum di pengadilan. Wacana humor pada data (5) terkesan membingungkan, tetapi di situlah letak paradoks berperan. Tokoh saksi di pengadilan tersebut mengeluarkan pernyataan yang bermakna seolaholah pertanyaan tadi tidak ditujukan kepada dirinya, tetapi kepada hakim. Dengan pemanfaatan gaya bahasa paradoks tersebut wacana humor di atas lebih memiliki nilai rasa humor.

\section{Data 6}

\section{Vonis Koruptor}

Seorang pejabat bernama Joni divonis 5 tahun penjara. Hakim juga memerintahkan menyita uang Rp50 miliar yang menjadi bukti kejahatan Joni. Joni tampak santai menghadapi vonis tersebut. Para wartawan pun menanyakan kenapa dia kelihatan tak bersedih. "Vonis untuk saya lebih ringan dari pemerkosa. Memang uang bukti korupsi saya disita. Tapi kemarin saya baca hakim yang sama memerintahkan alat bukti pemerkosaan milik terdakwa disita negara. Nah, mendengar vonis itu, tentu vonis untuk saya lebih ringan, kan?"

(http://www.merdeka.com)

Konteks percakapan pada data (6) terjadi antara tokoh terdakwa Joni, seorang pejabat yang divonis lima tahun penjara karena korupsi. Sebagai bukti kejahatan, negara menyita uang Rp50 miliar dari terdakwa. Namun, terdakwa Joni tampak tidak terkejut dan tidak sedih dengan vonis tersebut. Setelah ditanya wartawan, terdakwa Joni pun mengakui bahwa vonisnya itu ringan, "Vonis untuk saya lebih ringan dari pemerkosa. Memang uang bukti korupsi saya disita. Tapi kemarin saya baca hakim yang sama memerintahkan alat bukti pemerkosaan milik terdakwa disita negara. Nah, mendengar vonis itu, tentu vonis untuk saya lebih ringan, kan?"

Keparadoksan terdapat pada wacana humor korupsi data (6) di atas terlihat pada kalimat yang diungkapkan tokoh terdakwa Joni kepada wartawan. Kalimat tersebut adalah Vonis untuk saya lebih ringan dari pemerkosa. Memang uang bukti korupsi saya disita. Tapi kemarin saya baca hakim yang sama memerintahkan alat bukti pemerkosaan milik terdakwa disita negara. Nah, mendengar vonis itu, tentu vonis untuk saya lebih ringan, kan? Hal itu tentu tidak masuk akal. Ketidakmasukakalan itulah gaya paradoks yang nyata menentang fakta yang sebenarnya terjadi.

Adapun implikasi makna dalam wacana humor korupsi data (6) antara lain vonis terdakwa kasus korupsi sangat ringan dibandingkan dengan kejahatan lain, padahal tindakan korupsi selain sangat merugikan bangsa dan negara serta menyengsarakan rakyat, vonis terdakwa kasus korupsi tidak berat sehingga tidak membuat jera para pelakunya, dan vonis terdakwa kasus korupsi sangat tidak sebanding dengan kerugian yang diakibatkannya. Kreator wacana humor dengan sengaja menggunakan gaya bahasa paradoks pada data (6) di atas sebagai sumber kelucuan pada wacana humor tersebut.

\section{PENUTUP}

Berdasarkan temuan dan pembahasan dapat disimpulkan bahwa semua data dalam wacana humor korupsi tersebut memanfaatkan salah satu gaya bahasa, yakni paradoks. Dikatakan memanfaatkan paradoks karena keenam data tersebut semuanya memiliki ciri 
gaya bahasa paradoks. Ciri gaya bahasa paradoks adalah mengandung pertentangan yang nyata dengan fakta yang sesungguhnya terjadi.

Adapun implikasi makna dari gaya bahasa paradoks dalam keenam data wacana humor bertemakan korupsi antara lain banyaknya manusia yang tidak jujur, koruptor Indonesia sangat profesional, kearoganan yang sering ditunjukkan oleh para penguasa atau pejabat dalam berbagai kesempatan, para pejabat pemerintahan dan unsur yang terkait menjadikan korupsi sebagai gaya hidup mereka, banyaknya praktik korupsi yang marak dilakukan oleh aparat penegak hukum (pengadilan), dan vonis terdakwa kasus korupsi sangat ringan.

\section{DAFTAR PUSTAKA}

Keraf, G. (2008). Diksi dan Gaya Bahasa. Jakarta: Gramedia Pustaka Utama.

Kridalaksana, H. (2001). Kamus Linguistik. Jakarta: Gramedia Pustaka Utama.

Kurniati, A. (2014). Kritik Politik dalam Humor: Kajian Implikatur Percakapan. Suar Betang, IX (2).

Lestari, F. I. (2013). Gaya Bahasa dan Tema Humor yang Terdapat dalam "Sontoloyo" Harian Meteor. SulukIndo, 2(1), 175-201.

Rahayu, N. P. (2014). Pelanggaran Maksim Kerja Sama Grice dalam Komik Humor Perancis Les Blondes Tome 1. Jurnal Ilmiah Mahasiswa FIB, 6(5).

Riniwati, S. A. (2011). uturan Humor dalam Wacana Wayang Mbeling di Harian Suara Merdeka. Jurnal Penelitian Inovasi, 36(1), 87-101.

Rohim, R. (2014). Cerita Humor Pak Pandir. Atavisme, 17(1), 85-95.
Santoso, W., Hermintoyo, M., dan Tiani, R. (2012). Pelanggaran Prinsip Kerja Sama, Implikatur Percakapan, dan Tema dalam Wacana Humor Politik. SulukIndo, 1(2), 49-60.

Sudaryanto. (1993). Metode dan Aneka Teknik Analisis Bahasa. Yogyakarta: Duta Wacana University Press.

Surachmi, S. (2011). Eufemisme dalam Wacana Humor Program Opera Van Java (OVJ) di Trans 7. Jurnal Pendidikan Bahasa Dan Sastra, 10(1), 22-29.

Zaimar, O. K. S., dan Harahap, A. B. (2015). Teori Wacana. Jakarta: Penaku. 